\title{
PERLINDUNGAN HUKUM DAMPAK PENGELOLAAN PERTAMBANGAN BATUBARA BERKELANJUTAN : ESENSI PENATAAN RUANG DALAM UNDANG-UNDANG NOMOR 5 TAHUN 1960
}

Oleh:

\author{
Siti Kotijah*
}

\begin{abstract}
Abstrak
Pengelolaan pertambangan tidak lepas dari penggunaan tanah dibawah permukaan bumi. Hal ini terkait dalam Pasal 2 ayat (2) dan (3), Pasal 9 ayat (2), serta Pasal 10 ayat (2) dan (2), Undang Undang Nomor 5 Tahun 1960 tentang Peraturan Dasar PokokPokok Agraria. Pengelolaan pertambangan batubara merujak dalam Undang-Undang Nomor 4 Tahun 2009 tentang Pertambangan Mineral dan Batubara. Perlindungan hukum pengelolaan pertambangan batubara berkelanjutan, dan hubungan dengan penataan ruang mengaju pada Pasal 6, Pasal 14 ayat (1) dan Pasal 18 Undang Undang Nomor 5 Tahun 1960, yang terkait rencana kota dalam penataan ruang dengan keterbukaan para pihak pemerintah terhadap masyarakat mengenai RTRW akan dilaksanakan.
\end{abstract}

Kata Kunci: Penataan ruang, tanah, Environmental (lingkungan), Tambang batubara

\section{PENDAHULUAN}

Pasal 28 ayat (1) Undang-undang Dasar 1945, mengisyaratkan bahwa hak lingkungan yang baik dan sehat tidak hanya merujuk pada fisik lingkungan hidup, lebih dari itu hak atas lingkungan hidup layak dsan bersih sebagai essensi dan eksitensi manusia untuk dijamin agar terpenuhinya hak hidup manusia secara hakiki. Untuk hak atas lingkungan yang baik dan sehat dalam hukum nasional, secara tegas dicantunkan dalam Pasal 65 ayat (1) Undang-undang

\footnotetext{
Fakultas Hukum Universitas Mulawarman, fafa law@yahoo.com
}

Nomor 32 Tahun 2009 tentang Perlindungan dan Pengelolaan Lingkungan Hidup, menyatakan bahwa:

1) Setiap orang berhak atas lingkungan yang baik dan sehat sebagai bagian dari hak asasi manusia;

2) Setiap orang berhak mendapat pendidikan lingkungan hidup, akses partisipasi, dan akses keadilan dalam memenuhi hak atas lingkungan hidup yang baik dan sehat;

3) Setiak orang berhak mengajukan usul/dan/atau keberatan terhadap rencana usaha dan/atau kegiatan yang 
diperkirakan dapat menimbulkan dampak terhadap lingkungan hidup;

4) Setiap orang berhak untuk berperan dalam perlindungan dan pengelolaan lingkungan hidup sesuai dengan peraturan perundang-undangan;

5) Setiap orang berhak melakukan pengaduan akibat dugaan pencemaran dan/atau perusakan lingkungan hidup.

Secara umum, ketentuan diatas dapat diartikan betapa penting kompenan lingkungan hidup dalam menunjang dan memenuhi hak hidup manusia. Untuk itu pengelolaan lingkungan harus sesuai dengan prinsip-prinsip pembanguna berkelanjutan.

Pentingnya pembangunan berkelanjutan, dengan menyimbangkan atau mengharmonisasikan antara pembangunan ekonomi dengan daya dukung lingkungan mengacu pada prinsip 1 Rio prinsip The Rio Declaration on Environment and Development, 1992, bahwa:1 "Human being are at centre of concerns for sustainable development. They are entitled to a healthy and productive life in harmony with nature. Sebagai upaya penerapan Agenda 21, pemerintah Indonesia pada tahun 1995, telah menyusun Agenda 21 Indonesia. Bagian IV: Pengelolaan Sumber daya Alam, Bab (16) Konservasi Keanekaragaman Hayati.

Pengelolaan pertambangan batubara yang berkelanjutan, berpedoman pada pengelolaan usaha pertambangan yang

${ }^{1}$ Konferensi UNCED yang juga dikenal dengan nama Earth Summit menghasilkan : a). Convention on Biological Diversity, b) Convention on Climate Change, c) Agenda 21, d) The Forest Prinsip, dan e). Rio Declaration on Environmenta and Development. ramahlingkungan, diaturdalamperlindungan lingkungan hidup dalam Energy Charter Treaty (selanjutnya disebut ECT). Dalam preambul ETC terdapat beberapa paragraf yang berkaitan dengan lingkungan. ${ }^{2}$ Pernyataaan diatas, menguraikan tentang arti pentingnya efesiensi dalam eksplorasi, produksi, konversi, penyimpangan, pengangkutan distribusi dan penggunaan energi. Dalam Pasal 18 ETC, diatur tentang kedaulatan terhadap sumber daya energi. ${ }^{3}$

Pasal 33 ayat (3) UUD 1945 dan Pasal 1 ayat (2) serta Pasal 2 ayat (1) UndangUndang Pokok Agraria nomor 5 Tahun 1960,

${ }^{2}$ Preambul ETC yakni 1). Recognizing the necessity for the most effecient exploration, production, conversion, storage, transport, distribution, and use of energy, 2). Recalling the United Nations Framework Convention on Climate Change, the Convention on Long-Range Transboundary Air Pollution and its Protocols, and other International Environmentl agreements with energyrelated aspects, and 3).Recognizing the increasingly urgent need for measures to protect the environment, including the decommissioning of energy installations and waste disposal, and for internationally-agreed objectives and criteria for these purposes.

${ }^{3}$ Pada Ayat (1) Pasal 18 ETC, menegaskan kedaulatan negara dan hak berdaulat terhadap sumber daya energi, dan ini dilaksanakan sesua dengan aturan-aturan hukum internasional, Ayat (2), bahwa kedaulatan tidak akan mempengaruhi tujuan untuk melakukan promosi sumberaya energi eksporasi dan pembangunan, dan ECT tidak akan merugikan aturan yang dibentuk oleh anggota yang berkaitan dengan kepemilikan sumber daya energi, Ayat (3) mengatur bahwa setiap negara berhak untuk menentuan area geografi untuk melakukan eksplorasi dan pembangunan sumberdaya energinya, mengoptimalkan pendapatan dan tingkat dimana dilakukan eksploitasi, menspesifikan, dan menikmati pajak, royalti atau bentuk pembayaran lainnya berdasarkan eksplorasi dan eksploitasi, serta mengatur lingkungan dari aspek keamanan dari ekslorasi dan eksploitasi, termasuk partisipasi langsung dari pemerintah dan perusahaan pemerintah, dan Ayat (4), mengatur bahwa anggota menfasilitasi akses terhadap sumberdaya energi, termasuk dengan tindakan non-discriminatory, pada kriteria yang dipublikasikan, lisensi, konsesi, dan kontrak untuk melakukan prospek dan eksplorasi atau eksploitasi atau menggali sumberdaya energi. 
menempatkan hak menguasai negara sebagai dasar dan asal dari hak-hak keagrariaan. Dari kekuasaan negara ini kemudian dikeluarkan kekuasaan-kekuasaan dalam ukuran yang lebih kecil, yang dalam bentuk, isi, dan sifatnya beraneka ragam. Fungsi individualistis dari kekuasaan negara artinya fungsi untuk membuat anggota masyarakat dalam perseorangannya menjadi berada di dalam kemungkinan keadaan sejahtera ${ }^{4}$.

Undang-undang Nomor 5 Tahun 1960 tentang Peraturan Dasar PokokPokok Agraria, selanjutan disebut dengan UUPA, sebagai dasar hak penguasaan negara atas bumi, air dan ruang angkasa, termasuk kekayaan alam yang terkandung didalamnya termasuk pertambangan batubara. Pengelolaan pertambangan tidak lepas dari tanah, dalam implementasi asas perlekatan, ${ }^{5}$ pemilik tanah pada negara menggunakan haknya atas ruang bawah tanah berupa penguasaan mineral deposit tambang batubara. Dalam hal ini sebatas benda-benda mineral yang bersifat padat

\footnotetext{
${ }^{4}$ Ibid, h.154.

${ }^{5}$ Asas perlekatan, bahwa pemilik tanah memberikan kewenangan untuk menggunakan tanahnya juga berwenang pula terhadap ruang udara yang ada diatasnya serta berhak atas ruang bawah tanah (right bellow the surface of land). Hak ini meliputi right to mineral deposit, right to items found in the land, and right to space below the surfacen dan karenannya penggunaan atas ruang tersebut tanpa ijin dari pemiliknya dipandang sebagai bentuk gangguan atau pelanggaran terhadap hak tanah, John Stevens and Robert A. Pearces, Sweet \& Maxwells Text Book Series, 1998, h.3.
}

(hard mineral ${ }^{6}$ ). Hubungan hukum dalam pengelolaan pertambangan batubara, terkait pengaturan pertambangan yang diatur di UUPA.

Konsep hukum agraria dalam arti luas, mencakup hukum pertambangan terkait dengan hak pertambangan dan pengelolaannya. Konsep agraria mengaju pada Undang Undang Nomor 5 Tahun 1960 tentang Peraturan Dasar Pokok-Pokok Agraria(UUPA).KontruksiUndang-Undang Pokok Agraria Dalam Perlindungan Hukum Pengelolaan Pertambangan Batubara Berkelanjutan.

\section{Konsep Agraria}

\section{Dalam Black's Law Dictinary} disebutkan bahwa arti agrarian is relating to land or to a division or distribution of land: as an agraria laws. ${ }^{7}$ Pengertian agraria dan hukum agraria dalam UUPA dipakai dalam arti yang sangat luas. Pengertian agraria meliputi bumi, air, dan kekayaan alam yang

${ }^{6}$ Sedangkan untuk benda mineral yang berbentuk cari atau gas dipandang kurang tepat. Secara almiah bendabenda mineral yang berbentuk cair atau gas dapat mengalir atau bergerak dari lokasi yang satu kelokasi yang lainnya menurut keadaan, sebaliknya benda-benda mineral yang terbentuk padat tetap berada pada tempatnya. Hal ini sesuai dengan teori rule of capture yang diberlakukan khusus terhadap benda-benda mineral yang berbentuk cair dan gas, dengan menyatakan bahwa: ..the owner of the track of land acquires title to the oil and gas that he produces from wells drilled thereon, thought it may be proved that part of such oil and gas migrated from adjoining lands. Teori yang jadikan landasan Texax Supreme Court melalui putusannya dalam mengadili perkara antrara Getty Oil melawan Joness tahun 1971 dan perkarea Sun Oil melawan Whitaker tahun 1972, lihat Lowe John, Oil and Gas Law, West Publishing, Co, St, Paul, Minnecapolis, 1995, h.8. Eman, Asas Pemisahan Horisontal Dalam Hukum Tanah Nasional, di Sampaikan pda pengukuhan Jabatan Guru Besar dalam bidang ilmu hukum agraria, pada Fakultas Hukum Universitas Airlangga, Surabaya, hari sabtu, 13 Desember 2008.

${ }^{7}$ Herny Campbell Black, Black Law Dictionary, West Publishing, Co, USA, 1991, h. 43. 
terkandung didalamnya. ${ }^{8}$

Pasal 33 ayat (3) secara terminologi, dan substasi, " bumi dan air dan kekayaan alam yang terkandung didalamnya. Bumi $^{9}$ dalam UUD 1945, adalah tanah berikut kekayaan alam yang dikandung didalamnya. Pengertian permukaan bumi

${ }^{8}$ Dalam batas-batas seperti yang ditentukan dalam Pasal 48 UUPA, bahkan meliputi juga ruang angkasa, yaitu ruang atas bumi dan air yang mengandung; tenaga dan unsur-unsur yang dapat digunakan untuk usahausaha memelihara dan memperkembangkan kesuburan bumi, air, serta kekayaan alam yang terkandung di dalamnya dan hal-hal lainnya yang bersangkutan dengan itu. Pengertian bumi meliputi permukaan bumi (yang disebut tanah) tubuh bumi dibawahnya serta yang berada dibawah air (Pasal ayat (4) jo Pasal 4 ayat (1) UUPA). Dengan demikian tanah meliputi permukaan bumi yang ada didaratan dan permukaan bumi yang berada dibawah bumi, termasuk air laut), Budi Harsono, Hukum Agraria Indonesia; Sejarah Pembentukan Undag-Undang Pokok Agraria Isi dan Pelaksanaannya, Jilid 1 Hukum Pertanahan Nasional, Djamabatan, Jakarta, 2003. Ada beberapa pendapat, tentang pengertian agraria menurut Andi Hamzah, agraria adalah masalah tanah dan semua yang ada diada didalam dan diatasnya, (Andi Hamzah, Kamus Hukum, Ghalia Indoensia, Jakarta, 1986, h.32.). Menurut Subjekti dan Tjitrospedibjo, agraria adalah urusan tanah dan segala apa yang ada didalam dan diatasnya. Apa yang ada didalam tanah misalnya batu, kerikil, tambang, sedangkan yang ada diatas tanah dapat berupa tanaman, dan bangunan. (Subektik dan R. Tjitorosedibio, Kamus Hukum, Pradnya Paramita, Jakarta, 1983, h.12.). menurut Urip Santoso, pendapat Andi Hamzah dan Subektik dan R. Tjitorosedibio, mirip dengan pengertian real estate yang dikemukakan oleh Arthur P. Crabtree, yang mengemukakan bahwa hak milik (property) dibagi menjadi dua (2) macam, yaitu: 1. real property atau juga disebut real estate adalah tanah dan segala sesuatu yang secara permanen melekat pada tanah (real estate is land and everything that is permanently attached to it (land), dan 2 personal property, apabila sesuatu (benda) itu terlepas dari tanah. Lihat Arthur P. Crabtree, You and The Law, Chapter VI dan Urip Santoso, Hukum Agraria dan Hak-hak Atas Tanah,Prenada, Jakarta, 2005, h.2. A.P. Parlindungan, mengemukakan agararia mempunyai ruang lingkup, yaitu dalam artian sempit, bisa berwujud hak-hak atas tanah, ataupun pertanian saja, sedangkan Pasal 1dan Pasal 2 UUPA telah mengambil sikap dalam pengertian yang meluas, yaitu bumi, air, ruang angkasa, dan kekayaan alam yang terkandung didalamnya, (A.P.Parlindungan, Komentar Atas Undang-undang Pokok Agraria, Mandar Maju, Bandung, 1991, h.36.

9 Andi Hamzah, Kamus Bahasa Indonesia, h.136, bumi memiliki arti planet tempat hidup, dunia dan jagad atau permukaan dunia, tanah. Pengertian bumi meliputi (a) permukaan bumi; (b) tubuh bumi dibawahnya; (c) tubuh bumi yang dibawah air. tersebut adalah tanah. Kata tanah memiliki arti permukaan bumi atau lapisan bumi yang diatas sekali, keadaan bumi disuatu tempat; permukaan bumi yang diberi batas. ${ }^{10}$ Kata tanah memiliki arti permukaan bumi atau lapisan bumi yang diatas sekali; keadaan bumi disuatu tempat, permukaan bumi yyang diberi batas. ${ }^{11}$ Pengertian air meliputi : (a) perairan pedalamn: (b) laut wilayah Indonesia. Dengan demikian seluruh kekayaan alam yang yang terdapat di air juga dikuasai dan dipergunakan untuk sebesar-besarya kemakmuran rakyat. Ditinjau dari segi makan, baik yang tersirat maupun yang tersurat dalam Pasal 33 ayat (3) UUD. Makna tersebut berorintasi karena menjadikan sumber daya alam sebagai kekayaan alam yang bernilai ekonomis walaupun penggnaan dan pemanfaatan kekayaan alam adalah untuk kemakmuran sebesar-besarnya rakyat.

Konsep dasar hak menguasai negara atas kekayaan sumber daya berupa sumber batubara oleh negara termuat dalam Pasal 33 ayat (3) UUD 1945 yang bahwa "Bumi dan air dan kekayaan alam yang terkandung didalamnya dikuasai oleh negara dan dipergunakan untuk sebesar-besarnya kemakmuran rakyat. Makna dikuasai negara

${ }^{10}$ Maria S.W.Sumardjono, Aspek Yuridis dan Sosial Ekonomi Dalam Pelaksanaan Kondosilasi Pertanahan, makalah pada lokakarya konsolidasi tanah, semarang 1213 Desember, 1990. h.1.

11 Dalam Black Law Dictionary : land may include any estate or interest in lands, either legal or equitable. As well as easements and inconporeal hereditaments, Henry Cambell Black, Black's Law Dictionary, St Paul Minn USA, 1990, h.235. dalam pengertian lain kata tanah adalah terjemahaan dari kata land (Inggris) yang berati tanah atau ladang, akker (Belanda yang berarti ladang, tanah pertanian, Ager (Yunai) yang berarti tanah atau ladang, Agrarius (Latin yang berhubungan dengan tanah (ladang pertanian). Di Indonesia kata agrarias biasa disebut Agraria. 
dalam Pasal 33 ayat (3) merupakan dasar bagi konsep hak penguasaan negara. Hak penguasaan negara berisi wewenang yang diberikan oleh hukum untuk mengatur, mengurus dan mengawasi pengusahaan pertambangan batubara serta berkewajiban untuk mempergunakan sebesar-besarnya kemakmuran rakyat. Penguasaan oleh negara diselenggarakan oleh pemerintah. ${ }^{12}$ Pengertian dikuasai dalam ketentuan Pasal 33 ayat (3), ${ }^{13}$ dapat diartikan dalam hubungan antara negara dengan bumi, air dan kekayaan alam yang terkandung didalamnya adalah hubungan penguasaan. Artinya bumi, air, dan kekayaan alam yang

${ }^{12}$ Istilah pemerintahan dalam konitasi hukum adminitrasi Belanda menunjuk kepada istilah "bestuur" yang mencakup kepada 2 (dua) pengertian yaitu organ (badan), dan fungsi, sehigga makna pemerintah mengandung pengertian luas, Tatiek Sri Djatmiati, Prinsip Izin Usaha Industri Di Indonesia, Desertasi, 2004, h.59.

${ }_{13}$ Sejarah terbentuknya Pasal 33 ayat (3) UUD 1945, berawal pada saat R. Soepomo melontarkan idenya didepan sidang Badan Penyidik Usaha Persiapan Kemerdekaan Indonesia (BPUKPI) pada tanggal 1 Mei 1945, yang diakhir pidatonya tentang negara integralistik antara lain menyebutkan: Sekarang tentang hubungan antara negara dan perekonomian. Dalam negara yang berdasar integralistik, yang berdasar persatuan, maka dalam lapangan ekonomi akan dipakai sistem "sosialisme negara (staats socialisme). Perusahaan-perusahaan yang penting akan diurus oleh negara sendiri, akan ditetapi pada hakekatnya negara yang akan menentukan dimana dan dimasa apa atau perusahaan apa yang akan diselenggarakan oleh pemerintah pusat atau pemerintah daerah atau yang akan diserahkan kepada suatu badan hukum privat atau kepadaa seseorang, itu semua tergantung daripada kepentingan negara, kepenting rakya seluruhnya. Dalam negara Indonesia baru, dengan sendirinya menurut keadaan sekarang, perusahaan-perusahaan sebagai lalu lintas, electriciteit, perusahaan alas rimba harus diurus oleh negara sendiri. Begitupun tentang hal tanah, pada hakekatnya negara yang menguasai tanah seluruhnya. Tambang-tambanng yang penting untuk negara akan diurus oleh negara sendiri. Melihat sifat masyarakat Indonesia sebagai masyarakat pertanian, maka dengan sendirinya tanah pertanian menjadi lapangan hidup dari kaum tani dan negara harus menjaga supaya tanah pertanian itu tetap oleh kaum tani. ( Risalah Sidang Badan Penyidik usaha-Usaha Persiapan Kemerdekaan Indonesia (BPUPKI), Panitia Persiapan Kemerdekaan Indonesia (PPKI) 29 Mei 194519 Agustus 1945, Seketariat Negara Republik Indonesia, 1992, h.35. terkandung didalamnya itu dikuasai oleh negara dan dipergunakan untuk sebesarbesarnya kemakmuran rakyat, termasuk dalam hal kekayaan sumber daya alam berupa batubara. ${ }^{14}$

Tanah mempunyai arti penting dalam kehidupan manusia karena mempunyai fungsi ganda, yaitu social asset dan capital assset $^{15}$. Bagi masyarakat hukum adat, tanah itu mempunyai kedudukan yang sangat penting, karena merupakan satu-satu benda kekayaan yang bersifat tetap dalam keadaannya, bahkan lebihmenguntungkan. Selain itu tanah merupakan tempat tinggal, tempat pencarian, tempat penguburan, bahkan menurut kepercayaan mereka adalah tempat tinggal dayang-dayang pelindung persekutuan dan para leluhur persekutuan. ${ }^{16}$ Tanah di bawah permukaan, berupa hasil tambang dikelola dan dimanfaatkan oleh perorangan, swasta, dan negara untuk kesejahteraan.

${ }^{14}$ Sebagai sumber hukum tertinggi dalam melakukan pengelolaan dan pengusaan terhadap sumber daya alam, termasuk batubara adalah Pasal 33 ayat (3) UUD 1945, bahwa" Bumi dan air dan kekayaan alam yang terkandung di dalamnya dikuasai oleh negara dan dipergunakan untuk sebesar-besarnya kemakmuran rakyat. Makna " dikuasai oleh negara" tidak ada penjelasan secara kongkrit dalam hukum kita.

${ }^{15}$ Sebagai sosial asset tanah merupakan sarana pengikat kesatuan sosial dikalangan masyarakat Indonesia untuk kehidupan, sedangkan capital asset tanah merupakan faktor modal pembangunan, Hermin Yulis, Aspek-aspek Hukum Pakai Hak Tanah Negara sebagai Objek Jaminan, Hukum Bisnis, Vol. 10, Jakarta h.49. dikutif Sri Hayati dalam Pidato Pengukuhan Guru Besar dalam bidang hukum perdata Fakultas Hukum Universitas Airlangga, Surabaya, Berjudul Restrurisasi Hak Atas Tanah Dalam Pembaharuan Hukum Agraria Nasional, pada tanggal 5 Maret 2005, h.2.

${ }^{16}$ Soerojo Wignjodipoerno, Pengantar dan AsasAsas Hukum Adat, penerbit alummi, Bandung, 1997, h.237. 


\section{Kontruksi Undang-Undang Pokok} Agraria Dalam Perlindungan Hukum Pengelolaan Pertambangan Batubara

\section{Berkelanjutan}

Pasal 2 ayat (2) UU No.5 Tahun 1960 tentang UUPA, ${ }^{17}$ dalam wewenang menguasai dalam konsep hak menguasai negara digunakan untuk mencapai sebesar-besarnya kemakmuran rakyat dan pelaksanaanya dapat dikuasakan kepada daerah dan masyarakat hukum adat. ${ }^{18}$ Negara tidak memiliki, melainkan bertindak selaku pemegang kekuasaan. Jadi bersifat publik atau pemerintah berlaku (berstuursdaat). Dasar tujuan dikonsep dikuasai negara dalam Pasal 33 ayat (3) UUD 1945 maupun UUPA ditegaskan bahwa hak menguasai oleh negara adalah sebesar-besarnya kemakmuran rakyat. Berdasarkan tujuan disebut, ada beberapa larangan yang tidak boleh dilanggar, yaitu:

a. Apabila dengan iktikad baik tanahtanah telah dikuasai dan dimanfaatkan oleh rakyat, maka pernyataan itu harus dihormati dan dilindungi. Keberdaan rakyat ditanah-tanah tersebut merupakan salah satu penjelmaan dari tujuan kemakmuran rakyat. Rakyat harus mendapat hak didahulukan dari pada accupant baru yang menyalagunakan formalitas-

${ }^{17}$ Hak menguasai negara" sebagai wewenang untuk:Mengatur dan menyelenggarakan perubahan, penggunaan, persedian, dan pemeliharan bumi, air, dan ruang angkasa tersebut;Menentukan dan mengatur hubungan-hubungan hukum antara orang-orang dengan bumi, air, dan ruang angkasa; dan Menentukan dan mengatur hubungan-hubungan hukum mengenai bumi, air, dan ruang angkasa.

${ }^{18}$ Pasal 2 ayat (3) dan (4) UU No.5 Tahun 1960 tentang Pengaturan Dasar Pokok-Pokok Agraria. formalitas hukum yang berlaku; dan

b. Tanah yang dikuasai negara, tetapi telah dimanfaatkan rakyatdenga iktikat baik (ter geode throuw) hanya dapat dicabut atau diasingkan dari mereka, semata-mata untuk kepentingan umu, yaitu untuk kepentingan sosial dan/ atau kepentingan negara. ${ }^{19}$

c. Setiap pencabutan atau pemutusan hubungan hukum atau hubungan kongkrit yang diduduki atau dimanfaatkan dengan iktikad baik, harus dijamin tidak akan menurunkan status atau kualitas mereka karena hubungan mereka dengan tanah tersebut. $^{20}$

Di Indonesia dikenal dengan konsep pemisahan pengaturan antara kekayaan alam yang berada " dibawah tanah atau " dikandungan bumi" yang berbentuk bahan tambang galian dengan ketentuan mengenai

${ }^{19}$ Kepentingan umum biasanya dipadankan dengan publek belang. Pemikiran yang menunjuk pada alegemen atau general purpose, yang dibedakan menjadi kepentingan sosial (sociale belangen, social purposes) dan kepentingan negara atau untuk menyelenggarakan kekuasaan publik (inilah yang disebut kepentingan publik atau publiek belang atau publiek purpose). Dalam hubungan ini Roscoe Pound membedakan tujuan hukum kedalam individual interest, social interest, dan publik interest.

${ }^{20}$ Pengertian dikuasai menurut Mohammad Hatta. Dikuasai negara tidak berarti negara sendiri menjadi pengusaha, usahawan atau ordernemer. Lebih tepat dikatakan bahwa kekuasaan negarea terdapat pada membuat peraturan guan kelancaran jalan ekonomi, peraturan yang melarang pula penghisapan orang yang lemah oleh orang yang bermodal. Kemudian Pengertian dikuasai negara menurut Bagir Manan.

1. Penguasaan semacam pemilikan oleh negara, artinya negara melalui pemerintah adalah satu satunya pemegang wewenang untuk menentukan hak, wewenang atasnya, termasuk disini bumi, air, dan kekayaan alam yang terkandung didalamnya;

2. Mengatur dan mengawasi penggunaan dan pemanfaatan; dan

3. Penyertaan modal dan dalam bentuk pengusahaan negara. 
tanaman yang berada dipermukaan bumi atau tanah di wilayah hukum Republik Indonesia. ${ }^{21}$ Bahan galian tambang, termasuk batubara pun dibedakan antara bahan tambang yang asal dari karbon atas kandungan minyak dan gas dengan bahan tambang umum yang berbentuk keras.

Mengaju pada ketentuan Pasal 2 ayat (2) dan (3), Pasal 9 ayat (2), serta Pasal 10 ayat (2) dan (2), pemerintah dalam rangka sosialisme Indonesia, membuat suatu rencana umum mengenai persedian, peruntukan dan penggunaan bumi, air, dan ruang angkasa serta kekayaan alam yang terkandung didalamnya: salah satunya keperluaan memperkembangkan industri, transmigrasi dan pertambangan. Bidang pertambangan sudah diatur dalam UUPA, lebih khususnya diatur dalamUUNo.4 Tahun 20009 tentang Pertambangan Mineral dan Batubara. Pengaturan pertambangan tidak bisa dilepaskan dari tanah, yang dimaknai tanah secara UUPA, pertambangan sumber kakayaan alam yang terdapat dibawah tanah.

\section{Dalam memori penjelasan II/8} UUPA, bahwa tanah untuk persedian,

${ }^{21}$ Asas Pemisahan Horizantal merupakan hak atas tanah tidak sendirinya meliputi pemilikan bangunan dan tanaman yang ada diatasnya, perbuatan hukum mengenai tanah tidak dengan sendirinya meliputi bangunan dan tanaman yang berada diatasnya. Namun dalam praktik dimungkinkan suatu perbuatan hukum mengenai tanah meliputi juga bangunan dan tanaman yang diatasnya. Hal ini dengan syarat:

1. Bangunan dan tanaman tersebut secarea fisik merupakan kesatuan, dengan tanah yang bersangkutan, artinya bangunan yang berpondasi dan tanaman merupakan tananaman keras;

2. Bangunan dan tanaman keduanya merupakan kepunyaan pemiliknya; dan

3. Maksud demikian secara tegas disebutkan di dalam akta yang membuktikan dilakukan perbuatan hukum yang bersangkutan. peruntukan, dan penggunaanya harus melalui suatu perencanaan. Perencanaan ini dapat ditafsirkan, bahwa UUPA, dalam penggunaan kawasaan pertambangan, harus ada perencanaan dalam RTRW suatu propinsi/kabupaten/kota dalam suatu proses pembangunan. Peruntukan itu dalam rangka tata ruang pengelolaan petambangan, yang berhubungan dangan pengembangan wilayah suatu daerah propinsi/kabupaten// kota dalam pembangunan yang akan dilakukan.

\section{Hubungan pertambangan dengan penataaan ruang}

Dasar hukum penataan kota mengacu pada dasar hukum penataan ruang antara lain diatur dalam Pasal 14 ayat (1) UUPA, yang dalam peruntukan dan penggunaan bumi, air dan ruang angkasa serta kekayaan alam yang terkandung di dalamnya, salah satunya pertambangan. Penatagunaan tanah ini diwujudkan dalam suatu rencana tata ruang. Penataan ruang di atur dalam UU No.26 Tahun 2007 tentang Penataan Ruang. Dalam tindakan penataan ruang sesuai dengan rencana tata ruang akan menimbulkan akibat-akibat hukum sesuai dengan hak atas tanah. ${ }^{22}$ Ruang sebagai satu sumber daya alam tidak mengenal batas wilayah. Namun ruang dikaitkan dengan pengaturan, maka harus jelas batas, fungsi dan sistemnya dalam satu kesatuan. Aspek pertanahan dan penataan ruang

${ }^{22}$ Berdasarkan Pasal 16 UUPA: hak-hak atas tanah adalah hak milik, hak guna usaha, hak guna bangunan, hak pakai, hak sewa, hak membuka tanah, hak memungut hasil hutan. Hak-hak lain yang tidak termasuk hak-hak diatas akan ditetapkan dengan UU. 
Aspek pertanahan dan penataan ruang, mempunyai hubungan penting, karena tanah sebagia salah satu sumber daya kegiatan penduduk yang dapat dinilai sifat, proses dan penggunannya, ini sesuai dengan yang dikemukakan Firey, 23 "Tanah dapat menunjukan pengaruh budaya yang besar dalam adaptasi ruang, dan selanjutnya dikatakan ruang dapat merupakan lambang bagi nilai-nilai sosial ( misalnya penduduk sering memberi nilai sejarah yang besar kepada sebidang tanah). Dalam Pasal 18 UUPA, bahwa hak atas tanah adalah hak dan kewajiban, kewenangan-kewenangan dan manfaat dalam menggunakan tanah yang dengan sendirinya meliputi fisik tanah dan lingkunannya serta ruang diatasnya.

Penataaan ruang dan tata guna tanah, dalam Pasal 16 UUPA, mewajibkan pemerintah untuk menyusun rancangan umum mengenai persedian, peruntukan, dan penggunaan tanah untuk berbagai macam keperluan pembangunan. Dalam penataaan ruang terkait pengelolaan pertambangan, mengacu pada rencana umum peruntukan tanah, didasarkan pada kondisi obyektif fisik tanah dan keadaan lingkungan, baik ditingkat propinsi, dan kabupaten/kota harus memiliki kesamaan. Berdasar Perpres No.65 Tahun 2006 tentang

${ }^{23}$ Benjamin Abdulrahman, Pemahaman Dasar Regional Management dan Regional Marketing, Ikatan Ahli Perencanaan Indonesia, Semarang, 2005, h.3, kemudian Firely, Caphain, menggolongkan tanah dalam tiga kelompok:

a. Nilai keuntungan, yang berhubungan dengan nilai ekonomi, dan yang dapat dicapai dengan jual beli tanah dipasar bebas;

b. Nilai kepentingan umum, yang berhubungan dengan pengaturan untuk masyarakat umum dalam kebaikan kehidupan masyarakat; dan

c. Nilai sosial, yang merupakn hal yang mendasar bagi kehidupan.
Perubahan Atas Perpres No.36 Tahun 2005 tentang Pengadaan Tanah Bagi Pelaksanaan Pembangunan Untuk Kepentingan Umum, hal ini dalam pelaksanaa penetapan rencana pembangunan kepada kepentingan umum, sesuai dengan dan berdasarkan kepada Rencana Tata Ruang Wilayah (RTRW) yang ditetapkan lebih dahulu, termasuk dalam penetapan kawasan wilayah pengelolaan pertambangan.

Peran serta masyarakat dalam melaksanakan pembangunan, wujudnya dengan hak-hak dimiliki oleh masyarakat diambil, untuk wilayah pertambangan. Hal ini menunjuk pada Pasal 6 dan Pasal 14 UUPA, dalam pemanfaatan lahan atau peruntukan tanah, sehingga lahan terkena rencana kota, yaitu untuk pembangunan bidang pertambangan, maka masyarakat harus melepaskan kepemilikan tersebut, dengan melalui hibah atau ganti rugi.

Perlindunganhukumdalampengelolaan pertambangan yang berkelanjutan diterapkan oleh pemerintah dan pemerintah daerah terhadap lahannya yang terkena rencana kota adalah dengan keterbukaan pihak pemerintah terhadap masyarakat mengenai RTRW akan dilaksanakan. Bentuk perlindungan hukum yang lain pada masyarakat adalah dengan konsep ganti rugi yang dilakukan pemerintah terhadap lahan yang dimiliki masyarakat. Dengan demikian hak-hak dari masyarakat akan terlindungi dalam proses ganti rugi untuk lahan dalam pembangunan dibidang pertambangan. 


\section{Kesimpulan}

Pasal 2 ayat (2) dan (3), Pasal 9 ayat (2), serta Pasal 10 ayat (2) dan (2), Undang Undang Nomor 5 Tahun 1960 tentang Peraturan Dasar Pokok-Pokok Agraria, sudah mengatur pertambangan, yang secara khusus diatur dalam Undang-Undang Nomor 4 Tahun 2009 tentang Pertambangan Mineral dan Batubara. Perlindungan hukum pengelolaan pertambangan batubara berkelanjutan, dan hubungan dengan penataan ruang mengaju pada Pasal 6, Pasal 14 ayat (1) dan Pasal 18 Undang Undang Nomor 5 Tahun 1960, yang terkait rencana kota dalam penataan ruang dengan keterbukaan para pihak pemerintah terhadap masyarakat mengenai RTRW akan dilaksanakan.

\section{DAFTAR BACAAN}

Land Law In Comperative Perspective, KluwerLaw Internasional. Netherlands, 2002

Abdulrahman, Benjamin Pemahaman Dasar Regional Management dan Regional Marketing, Ikatan Ahli Perencanaan Indonesia, Semarang, 2005.

Budiharjo, Tata Ruang, Alumni, Bandung, 1997.

Butt, Peter, Hand Book of Singapura Law, Butterworths, Singapura, 1986.

Djatmiati, Tatiek Sri Prinsip Izin Usaha Industri Di Indonesia, Desertasi, Pascasarjana Universitas Airlangga, 2004.

E Utrecht, Hukum Pidana 1, Universitas Indonesia, Jakarta, 1956.

Eman, Asas Pemisahan Horisontal dalam
Hukum Tanah Nasional, Pidato Pengukuhan Jabatan Guru Besar Dalam Bidang Hukum Agraria, Fakultas Hukum UniversitasAirlangga Surabaya, Hari Sabtu, Tanggal 13 Desember 2008.

, Prinsip Hukum Ruang Bawah Tanah Untuk Bangunan Gedung Dalam Sistem Hukum Agraria Nasional. Desertasi, Pascasarjana Universitas Airlangga Surabaya, 2006.

Friendman, Lawrence M. Law and Society. An Introduction Englewood Cliffs, N.J. Prentice Hall, 1977.

Gautama, Sudargo, Tafsir Undang-undang Pokok Agraria, Citra Aditya Bakti, Bandung, 1990.

Gunagegara, Pengadaan Tanah Oleh Negara Untuk Kepentingan Umum, Desertasi, Pascasarjana Universitas Airlangga Surabaya, 2006.

Hayati, Sri dalam Pidato Pengukuhan Guru Besar dalam bidang hukum perdata Fakultas Hukum Universitas Airlangga, Surabaya, Berjudul Restrurisasi Hak Atas Tanah Dalam Pembaharuan Hukum Agraria Nasional, pada tanggal 5 Maret 2005.

Hadjon, , Philipus M. Perlindungungan Hukum Bagi Rakyat, Peradapan, 2000 .

H.L.A. Hart, The Concept Of Law, oxford university press, 1961.

Hatrik, HamzahAsas Pertanggungjawab Korporasi Dalam Hukum Pidana Indonesia (Strict Liability dan Vicarious Liability), Raja Grafindo Persada, 1995.

Harsono, Budi, Hukum Agraria Indonesia, Sejarah Pembentukan Undangundang Pokok Agraria, Isi, dan 
Pelaksanaannya, Djambatan, Jakarta, 1997.

Kleden, Ignas Kearah Pembangunan Bekelanjutan di Indonesia, dalam Buku pembangunan berkelanjutan, mencari format politik, Yayasan SPEDS, Gramedia Pustaka Utama Bekerjasama dengan Yayasan SIPES, Jakarta, 1992.

Komisi Dunia Untuk Lingkungan dan Pembangunan (WCED).

Kerap, Sonny, dalam Proceedings of Ninth Internasional Coral Reef Sysmsium, Bali, 23-27 Oktober 2000, Indonesia Institute of Science, Internasional Society for Regal Studies, 2002.

Parlindungan, A.P. Komentar Atas Undangundang Pokok Agraria, Mandar Maju, Bandung, 1991
Ridwan, juniarso, dkk, Hukum Tata Ruang; Dalam Konsep Kebijaksaan Otonomi Daerah, Nuansa, Bandung, 2008

Santoso, Urip, Hukum Agraria dan HakHak Atas Tanah, Kencana, Jakarta, 2005.

Sumardjono, Maria S.W, Aspek Yuridis dan Sosial Ekonomi Dalam Pelaksanaan Kondosilasi Pertanahan, makalah pada lokakarya konsolidasi tanah, semarang 12-13 Desember, 1990.

Subroto, Perencanaan Pengembangan Wilayah, Fajar Gemilang, Bandung, 2003.

Wignjodipoerno, Soerojo, Pengantar dan Asas-Asas Hukum Adat, penerbit alummi, Bandung, 1997. 